\title{
US agencies sift for wheat in 1988 budget chaff
}

\section{- AIDS research boosted - Some last-minute winners}

\section{Washington}

THREE months after the fiscal year began, the US federal government has received its spending authority from Congress for 1988. But even now, weeks after President Reagan signed the continuing resolution that authorizes just about every expenditure the government will make until September when this fiscal year ends, the various federal agencies are combing through the thousand-page law, trying to determine what restrictions have been placed on the money they have to spend.

In a year of belt-tightening, science budgets did not make out too badly. The National Science Foundation (NSF) was knocked off its course towards a doubling of its budget in the next five years, but it nonetheless received $\$ 1,717$ million, 5.8 per cent more than last year, but $\$ 176$ million less than had been requested.

Funds for research were set at $\$ 1,453$ million, 3.3 per cent more than 1987. Exactly how many of the new science and technology centres can be funded with the money available and how many individual grants can be awarded will be decided by the end of this month.

Although Congress has left to NSF most decisions about where to put its money, the agency was required to give $\$ 1.5$ million to a supercomputer centre that offers unique resources not available from those supercomputer centres already supported by NSF. This money will probably go to the University of Minnesota, which has the only Cray 2 supercomputer at an academic facility. Also mandated by Congress is $\$ 1$ million to IIASA, the International Institute for Applied Systems Analysis located in Laxenberg, Austria. In the past, the National Security Council has blocked grants to IIASA because of concern that sensitive information was leaking to the Soviet Union through IIASA.

The National Institutes of Health (NIH) also received their customary favourable treatment from Congress. The total sum amounted to $\$ 6,667$ million, up approximately $\$ 400$ million from last year. That amount will allow NIH to make between 6,000 and 6,100 new and competing grants. The budget for the Centers for Disease Control in Atlanta will be $\$ 772$ million, 75 per cent more than requested by the Reagan administration.

Congress also left most decisions on spending up to $\mathrm{NIH}$, but did insist that $\$ 22$ million be used for facilities devoted to coping with the public health crisis brought on by AIDS (acquired immune deficiency syndrome). Total AIDS funding to NIH was $\$ 448$ million, nearly half the total of $\$ 906$ million given to the Department of Health and Human Services for AIDS activities.

Congress has begun to show interest in the project to map and sequence the human genome. Federal money will come chiefly from two sources; approximately $\$ 17.2$ million for mapping efforts from NIH, and \$12.5 million from the Department of Energy (DoE) for its activities, including work already started at three national laboratories (see p. 103). NIH will also continue to support individuals working on efforts related to the project.

DoE has other big projects to contend with. Its 1988 budget includes some $\$ 25$ million for the Superconducting Super Collider. The agency expects to pick a site for the proton-proton collider this summer. But DoE has some tricky juggling to do. Although the Office of Energy Research received some $\$ 2,050$ million to spend, nearly 5 per cent of that total will have to be given to 'earmarked' funds, money that Congress specifically directs for spending in particular ways. This money often goes directly to universities, bypassing any form of merit review. The DoE basic energy science has been a favourite place for these earmarked funds to be hidden in the budget, as has the Agricultural Research Service's budget (see box). Although some universities have tried to resist the temptation to make such direct appeals for facilities through political muscle, Robert Rosenzweig, president of the American Association of Universities, expects the practice will increase unless the government seriously tries to establish a pool of money for new facilities for which universities can compete.

The National Aeronautics and Space Administration did fairly well in the 1988 budget. The space station will receive $\$ 425$ million for the year, plus some $\$ 80$ million carried over from 1987 money. But that is still $\$ 262$ million less than the agency had been seeking. Congress made smaller cuts in budgets for planetary science missions, Earth science missions, and its sounding rocket and balloon programme, providing the requested amount for the Hubble Space Telescope only after a fight. Work will also be able to proceed on a fourth shuttle orbiter to replace the Challenger.
More money in the pork-barrel for some

Washington

IN a few instances in its 1988 budget deliberations, Congress saw fit to dole out more money than requested by the Reagan administration. Research on AIDS (acquired immune deficiency syndrome) and scientific and engineering education are two areas that Congress felt deserved special financial attention. But sometimes money shows up in budgets at the last moment, and its appearance is based more on the political skill and muscle of a particular state's elected officials than on national priorities.

The facilities account of the Agricultural Research Service (ARS) is an example. ARS, the research arm of the US Department of Agriculture (USDA), received $\$ 540.7$ million for its 1988 budget, some $\$ 6.3$ million more than requested. But for facilities, ARS requested only $\$ 1$ million for a national seed storage facility in Fort Collins, Colorado. But after the ARS budget emerged from the House of Representatives Appropriations Committee, that amount had jumped to $\$ 14.7$ million, with money for research facilities at nine universitites and two USDA facilities around the country.

Not to be outdone, the Senate raised the facilities budget to $\$ 50.0$ million, adding five universities and four state facilities to the list of recipients. But that was not the end. When the conferees met to iron out differences in the two appropriations, the account rose yet again to $\$ 57.8$ million, with one new university coming into money. Several facilities got big boosts in the conference. Construction funds for the Agricultural Research Facility at Oregon State University jumped from $\$ 5$ million to $\$ 10$ million and the Center for Applied Aquaculture in Hawaii jumped from $\$ 850,000$ in the House version to $\$ 6.4$ million.

Congress has frequently chosen the ARS budget to make appropriations that go directly to universities rather than through a merit review process. It is a process that most deplore, but few can resist.

Joseph Palca

\section{Erratum}

In the advertisement of Dr Stefan Marinov's International Congress on Relativity and Gravitation, to be held in Munich on 22-24 April, the following errors unfortunately appeared:

page 2 , line 8 should read "...gauge transformations as conventionally taught. The potentials are absolute potentials."

page 2, line 21: "machine MAMUL" should be "Bul-Cub machine without stator".

page 2, line 32, “...name Einstein..." should be "...name of Einstein...".

The journal titles "Philosoph. Mag." and "Europhys. Lett." should have been italicized. 